\title{
Local varieties of Araucaria angustifolia (Bertol.) Kuntze (Pinales: Araucariaceae) in southern Brazil: A brief discussion about landscape domestication
}

\author{
Mário Muniz Tagliari * \\ Nivaldo Peroni \\ Laboratório de Ecologia Humana e Etnobotânica, Departamento de Ecologia e Zoologia \\ Ed. Fritz Müller, $2^{\circ}$ andar, sala 223 B \\ Universidade Federal de Santa Catarina, Campus Universitário Reitor João David Ferreira Lima \\ CEP 88010-970, Florianópolis - SC, Brasil \\ * Autor para correspondência \\ mario.tagliari@posgrad.ufsc.br
}

Submetido em 27/11/2017

Aceito para publicação em 10/08/2018

\section{Resumo}

Variedades locais de Araucaria angustifolia (Bertol.) Kuntze (Pinales: Araucariaceae) no sul do Brasil: uma breve discussão sobre domesticação de paisagens. A Araucária é uma espécie emblemática da Floresta Ombrófila Mista - FOM. O comércio do "pinhão", sua semente, é economicamente relevante para grupos regionais, influenciando no manejo e uso da espécie. As populações da espécie foram historicamente manipuladas pela ação humana, que identificam variedades locais, caracterizando certo grau de domesticação da espécie e da paisagem. Assim, o objetivo desse estudo foi identificar essas variedades, caracterizar o uso e manejo do "pinhão" em comunidades locais circundantes ao Parque Nacional de São Joaquim - PNSJ, e discutir interações homem-plantas que possam ser relevantes na estruturação de paisagens culturais domesticadas. Aplicamos questionários semi-estruturados a quinze agricultores-extratores no entorno do PNSJ. Realizando turnês guiadas, montamos nove parcelas de $1600 \mathrm{~m}^{2}$ para coleta de dados populacionais da Araucária. Nos questionários, quatro variedades foram citadas: "Cajuvá", "Macaco", "Do cedo" e "Do tarde" além de três variedades identificadas nas turnês-guiadas $(\mathrm{N}=54)$. Todos entrevistados afirmaram usar, direta/indiretamente, o "pinhão", além de citarem variedades que conhecem e/ou manejam na FOM, evidenciando processo de domesticação. A conservação da Araucária pode ser favorecida ao considerar populações humanas locais que usam e manejam os recursos dessa espécie, fortalecendo sua conservação ao nível de paisagens manejadas junto às Unidades de Conservação do estado.

Palavras-chave: Comunidades locais; Conservação; Manejo da Araucária; Paisagem cultural domesticada; Pinhão

\section{Abstract}

Araucaria is an emblematic species of Mixed Ombrophilous Forest (MOF). The pinhão (the seed of araucaria) commerce is economically important to regional groups, which influences the use and management of this species. Historically, araucaria populations were manipulated by humans, who identify local varieties, characterizing the possible domestication of the species and local landscape. Thus, the goals of this study were 
to identify araucaria varieties, to characterize the use and management of araucaria seeds (pinhões) in local communities surrounding São Joaquim National Park (SJNP), and to discuss human-plant interactions that are relevant to the structure of domesticated cultural landscapes. We conducted semi-structured surveys with fifteen farmer-extractors in the surrounding areas of SJNP, a federal conservation unit. Through guided tours, we set up nine 1,600 $\mathrm{m}^{2}$ plots for data collection. During the surveys, four varieties were mentioned, Cajuvá, Macaco, Do cedo and Do tarde, and three varieties were identified during the guided tours $(\mathrm{N}=54)$. All interviewees affirmed that they directly or indirectly use pinhão, which is evidence of a landscape domestication process. Araucaria can be favored by local human populations that use and manage the resources of this species, which strengthen its conservation in a managed landscape with conservation units.

Key words: Araucaria management; Conservation; Domesticated cultural landscape; Local community; Pinhão

\section{Introduction}

Forest cover in Brazil is continuously decreasing (KANIESKI et al., 2010). Among the six recognized biomes in Brazil, only $7.5 \%$ of the natural extent of the Atlantic Forest remains (RIBEIRO et al., 2009). This biome exhibits high endemism rates, exceptional habitat loss and is classified as a "hotspot" (MYERS et al., 2000) and a global biodiversity priority (BROOKS et al., 2006). The Atlantic Forest is the richest of Brazil's phytogeographic domains, with more than 16,000 species and $46 \%$ endemism (MYERS et al., 2000). In the southern Atlantic Forest region, in the states of Paraná (PR), Santa Catarina (SC) and Rio Grande do Sul (RS), Mixed Ombrophilous Forest (MOF) (IBGE, 2012) is a representative phytophisiognomy that covers 40,30 and $25 \%$ of the area, respectively (CARVALHO, 1994). Species in this region are adapted to lower temperatures and regular frosts during winter (RODERJAN et al., 2002) and are distributed at elevations between 500 and 1,200 meters (DUARTE et al., 2012). The MOF biome occurs naturally in the humid subtropical region of Brazil (IBGE, 2012) and is exclusive to the Western Hemisphere (THOMAS, 2012).

Araucaria angustifolia (Bertol.) Kuntze, known as araucaria or Paraná pine, is the most representative MOF plant species. It is characterized by its cylindrical trunk with branches that ramify at the apex, forming the most representative characteristic of the species, a typical chandelier or umbel canopy (CARVALHO, 1994). The species produces appreciated and nutritious nut-like seeds, known popularly as pinhões (REIS et al., 2014; MACHADO MELLO; PERONI, 2015). Due to unsustainable exploitation in the beginning of the 20th century (REIS et al., 2014), combined with agricultural expansion and urbanization (RIBEIRO et al., 2009; WREGE et al., 2016), the distribution area of araucaria was extremely reduced. The current forest cover of remnant araucaria populations is estimated to be between $5 \%$ (GUERRA et al., 2002) and $12 \%$ of the original extent (RIBEIRO et al., 2009), which is similar to the extent of MOF described above. Araucaria angustifolia is classified as critically endangered by the International Union for Conservation of Nature - IUCN Red List (THOMAS, 2012).

Conservation units (CU) are the main conservation strategy for araucaria. This strategy, particularly integral protection conservation units, excludes human populations from $\mathrm{CU}$ areas and does not take into account the historical or prehistorical aspects of human occupation and resource domestication (CLEMENT; JUNQUEIRA, 2010; REIS et al., 2014). In addition, historical interaction, mainly during the pre-Columbian era, with different traditional and indigenous people may have gradually transformed MOF landscapes during a domestication process (REIS et al., 2014). This relation can maintain or alter biodiversity and/or transform the landscape, resulting in a biocultural interaction (REIS et al., 2014). The idea of "natural" untouched ecosystems for conservation purposes ignores the presence of humans during the transformation of landscapes over centuries, such as in the Amazon rainforest over thousands of years (BALÉE, 2010; CLEMENT; JUNQUEIRA, 2010; LEVIS et al., 2017).

The area of occurrence of araucaria can be analyzed and discussed in terms of the interaction between landscape transformation by local communities and 
the natural aspects of the species. Gathering/extraction practices of pinhões, for instance, is a historical and actual ecological factor for local communities in MOF in southern Brazil (MACHADO MELLO; PERONI, 2015; ADAN et al., 2016). Pinhão seeds are identified by their morphology, size, color, seed maturation, taste or even ripening period (ZECHINI et al., 2012; ADAN et al., 2016). Local names are used to describe the pinhões according to their local characteristics, resulting in the classification of araucaria into ethnoecological varieties by local communities (REITZ; KLEIN, 1966; MATTOS, 1994; ADAN et al., 2016; SHIBATA et al., 2016). High intraspecific morphological variability may be a common scenario for species that underwent a domestication process (CLEMENT, 2006). It is relevant to understand the relationships that influence the landscape, as well as the historical use and knowledge of societies (CAPPARELLI et al., 2011; PROBER et al., 2011) distributed along the extent of MOF.

The use, consumption, variety identification and management of pinhões reveal a scenario that involves ecological and cultural aspects of araucaria in MOF outside CUs. Our goals of this study were to identify araucaria varieties, to characterize the use and management of araucaria seeds (pinhões) in local communities surrounding São Joaquim National Park and to discuss human-plant interactions, which can be relevant to the structure of cultural landscapes.

\section{Material and Methods}

\section{Study area}

The study was conducted along a MOF plateau in Santa Catarina State, between 2012 (data collection and interviews) and 2013 (data analysis and interview transcription), in the municipality of Urubici ( $28^{\circ} 00^{\prime} 54^{\prime \prime} \mathrm{S}$, 49³5'30”W). We selected areas around São Joaquim National Park (Figure 1), which is the main CU in the region.

FIGURE 1: The study area. Left, the integral protection conservation units distributed in the three southern Brazilian States (dark gray) are in blue: Rio Grande do Sul (RS), Santa Catarina (SC) and Paraná (PR). Right, location of São Joaquim National Park.

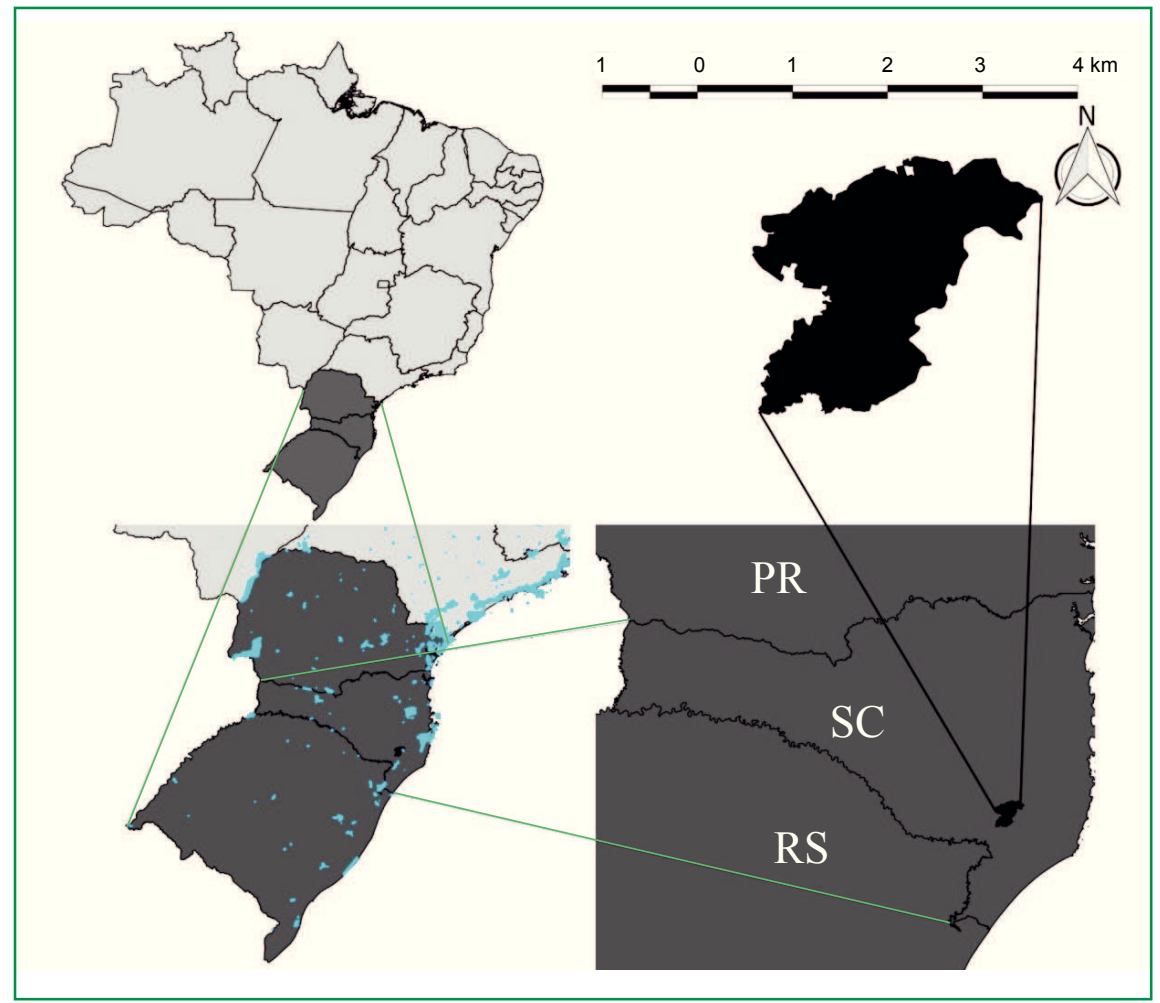




\section{Ethnoecological interviews}

In order to identify potential respondents for the interviews, we defined three conditions. First, the respondent indicated owns land near the CU. Second, the land must be a smallholding rural property. Since all properties are located in the surrounding areas of the São Joaquim National Park in the municipality Urubici, according to INCRA - National Institute for Agrarian Reform, the "smallholding properties" are up to 80 hectares or one to four fiscal modules (INCRA, 2013). Third, the respondent should directly or indirectly use pinhão seeds (e.g., selling, extracting, self-consumption). The interview used the snowball methodology, which consists of identifying the next potential respondent based on an indication by the present respondent (BAYLEY, 1994). The snowball technique is used to find research subjects and is an informal method to reach a target population (ATKINSON; FLINT, 2001). We considered the information gathering finished when one respondent indicated another respondent that had already been interviewed. This indicates the sufficiency of the number of respondents due to sample saturation (BERNARD, 2006). The interviews were semi-structured with structured and open-ended questions and aimed to understand the ethnoecological knowledge of the communities (see MACHADO MELLO; PERONI, 2015; ADAN et al., 2016). The interviews followed the prerogatives of Provisional Measure $n^{\circ}$ 2186-16 (23/08/2001) and used the consent form Termo de Anuência Prévia (see ADAN et al., 2016). We highlighted several topics in the interviews, such as the morphological description, commerce period, costumer preferences, and local variety names (see Appendix 1) of pinhões. We also estimated a consensus value for the araucaria varieties (CVV), which is calculated by dividing the number of citations of one specific local araucaria variety by the total number of citations. We could then describe the consensus among informants and understand how local knowledge is distributed in the study area (BYG; BALSLEY, 2001; MONTEIRO et al., 2006). The survey also aimed to describe the interaction of the local communities with the transformation of the araucaria landscape. Further, we described local problems cited by the communities and possible consequences on the target species. Due to ethical aspects, none of the respondents were identified during this study. All interviewees in this study were male $(\mathrm{N}=15)$ and varied from 45 to 70 years old (mean 53.4 years).

\section{Guided tours - Ethnoecological and ecological data collection}

To identify local varieties of araucaria we set some specific conditions. First, only the owner of the area, which included local farmers, landowners and/or seed extractors, could identify local varieties in the guided tours (ALBUQUERQUE et al., 2008). Second, the pinhão commerce would have to directly or indirectly influence the domestic income of the owner. Based on these two criteria, guided tours to collect ethnoecological information were possible. We randomly selected three landowners that were interviewed to participate in the guided tours, aiming to identify local araucaria varieties inside their properties. We delimited nine plots (40X40 $\mathrm{m} / 1600 \mathrm{~m}^{2} / 0.16 \mathrm{ha}$ ) in three private areas (i.e., three plots per property), which equaled $14,400 \mathrm{~m}^{2}$ or 1.44 ha. The plots were a minimum of $50 \mathrm{~m}$ apart and each plot was actively used for pinhão extraction. Inside the plots, besides the ethnoecological information collected, we identified aspects of the araucaria population structure by describing all specimens of four ontogenetic development classes (i.e., seedling, juvenile, adult male or female).

\section{Results}

Local araucaria varieties, influence of pinhão commerce on household income, and commercialization period

Local varieties/types of araucaria were grouped into four types: Cajuvá, Macaco, Do Cedo and Do Tarde; the Cajuva variety was the most cited (Table 1). As answered by the respondents, in relation to commerce $80 \%$ believe that customers do not recognize local varieties, as one landowner stated: "Being pinhão that's what matters," On the other hand, according to respondents, the Cajuvá variety is 
the most commercialized (in June and July). Several answers state that the variety is "the prettiest," "the sweetest" or even "redder." The Macaco variety was not cited by the farmers, landowners and/or seed extractors as a commercialized variety due to its late ripening period (August to November) and, according to one respondent, because "it does not detach from the branches." Among the 15 respondents, 66.5\% pointed out that "pinhão" commercialization influences their income, but only two declared that commercialization is highly important for them. The best months for the commercial varieties were May, June, and July (winter), as cited by $86.66 \%$ of the respondents $(\mathrm{N}=13)$. In the guided tours, each of the three landowners, seed extractors and/or smallholders helped us identify araucaria ethnovarieties inside their private areas. We identified 54 individuals of three varieties: Do cedo (23), Do Tarde (29), and Cajuvá (only two). We did not identify the Macaco variety inside the plots.

TABLE 1: Local pinhão varieties identified by the local communities (farmers, seed extractors), months of occurrence, consensus value for the variety (CVV) and commercialization ranking.

\begin{tabular}{|c|c|c|c|}
\hline Varieties & $\begin{array}{l}\text { Months of } \\
\text { occurrence }\end{array}$ & CVV & $\begin{array}{c}\text { Ranking of } \\
\text { Consensus Value } \\
\text { (CVV) }\end{array}$ \\
\hline Do Cedo & March until April & 0.30 & $2(0.13)$ \\
\hline Do Tarde & May & 0.17 & $2(0.13)$ \\
\hline Cajuvá & June and July & 0.31 & $1(0.26)$ \\
\hline Macaco & $\begin{array}{l}\text { August until } \\
\text { November }\end{array}$ & 0.22 & 4 (zero) \\
\hline
\end{tabular}

\section{Pinhão extraction and its natural production cycle}

When asked about seed extraction over the years, $87.5 \%$ of the respondents affirmed that there had been changes for harvesting pinhão; $61.5 \%$ believed that extraction increased, whereas $38.5 \%$ argued that the harvest decreased. Those who said harvesting has increased argued that this is due to proper legislation that avoided deforestation (13.5\%), resulting in a higher quantity of araucaria trees. Other respondents $(13.5 \%)$ claimed that nowadays there is more interest in consuming pinhões. Only two respondents (13.5\%) discussed that araucaria exhibits a lower and higher production cycle that sometimes causes an increase in pinhão harvesting. The respondents that said extraction has decreased cited climate variations (three respondents) and the araucaria cycle (two respondents). One respondent said the following: "The pinhão is cyclical, being productive for three consecutive years and rests two years." Another aspect about pinhão extraction mentioned by the respondents related to the natural factors that could interfere with pinhão production. Twenty percent cited that highly concentrated areas are not beneficial to araucaria, as described below:

"When the forest is too closed (dense forest - N.A.), the araucaria does not grow in diameter, and does not produce."

"Closed place (dense forest - N.A.) does not produce seeds, unlike the araucaria present in the clearings. With more araucaria, pinhão extraction tends to decrease."

\section{Ecological aspects of araucaria and local communities, a landscape perspective}

All respondents declared they were aware of legislation concerning the conservation of the species. Of them, $73.5 \%$ affirmed that thanks to the legislation there was an increase in the araucaria population, and $20 \%$ believed that pinhão commerce must increase in the future so araucaria conservation is relevant. Six landowners $(40 \%)$ think that the penalties for committing a crime are a reason for the increase. Another $60 \%$ answered that preservation among landowners is due to "ecological awareness." For those who argued that the araucaria population decreased after the national legislation (26.5\%), two major points were highlighted: seedling suppression and lack of effective enforcement. All respondents are aware of seedling suppression practices; nevertheless, in this study we did not ask them if they practiced seedling suppression. 
Guided tours to describe araucaria ecology and the opinion of respondents about araucaria conservation

In order to conduct a brief analysis of the araucaria populations inside the nine sampled plots (Table 2), we classified the species into four groups: seedlings, juveniles and male and female adults; adult identification was made by the landowner. In the plots, we found a lower percentage of seedlings (14.7\%) compared to juveniles (35.6\%), males (31.2\%) and females (18.5\%). When analyzing our semi-structured questionnaire, negative opinions about araucaria conservation laws were notable ( $20 \%$ among all respondents), as described below:

"[...] If it grows, it prejudices the pastures, which will only lead to losses, then people cut (seedlings or juveniles) because farmers will have no longer a production area for livestock."

"Government has taken a radical step fully prohibiting plant removal, so people were too radical, cutting to not have the hassle."
Four respondents $(27.5 \%)$ were favorable to araucaria management for conservation purposes, as an incentive for preservation or for subsistence (wood masonry). On the other hand, one interviewee declared that using araucaria resources should be explored extensively: "because it is a natural resource." Another respondent suggested that each private area should have its own management plan, so the wood can be used for subsistence. Finally, we asked the respondents if they believed in sustainable practices for resource use of araucaria and $73.3 \%$ answered that this is possible. When asked which practices they would suggest as sustainable, several proposals related to environmental management were described, such as encouraging planting with government subsidies, selective cutting of older trees, and tax compensation for araucaria management.

\section{Discussion}

There is a consensus among the local communities interviewed about the araucaria types inside the study area, where all respondents identified at least one

TABLE 2: Araucaria population identified in nine plots in the surrounding areas of the São Joaquim National Park. We used each landowner (LO) plot to identify four different araucaria stages: seedlings, juveniles, adult males, and adult females. The local owners of the area identified and classified the adult population.

\begin{tabular}{cccccc}
\hline Landowner Plots (LO) & Seedlings & Juveniles & $\begin{array}{c}\text { Adult } \\
\text { Males }\end{array}$ & $\begin{array}{c}\text { Adult } \\
\text { Females }\end{array}$ & Total \\
\hline LO1 - Plot 1 & 0 & 11 & 6 & 4 & 21 \\
LO1 - Plot 2 & 34 & 11 & 12 & 8 & 65 \\
LO1 - Plot 3 & 0 & 25 & 12 & 7 & 44 \\
LO1 - Total & 34 & 47 & 30 & 19 & 130 \\
\hline LO2 - Plot 1 & 0 & 10 & 12 & 3 & 15 \\
LO2 - Plot 2 & 0 & 13 & 4 & 2 & 19 \\
LO2 - Plot 3 & 3 & 12 & 14 & 10 & 39 \\
LO2 - Total & 3 & 35 & 30 & 15 & 83 \\
\hline LO3 - Plot 1 & 0 & 15 & 21 & 10 & 46 \\
LO3 - Plot 2 & 0 & 2 & 7 & 10 & 19 \\
LO3 - Plot 3 & 9 & 13 & 10 & 4 & 36 \\
LO3 - Total & 9 & 30 & 38 & 24 & 101 \\
\hline LO all Plots & 46 & 112 & 98 & 58 & 314 \\
Frequency (\%) & 14.7 & 35.6 & 31.2 & 18.5 & 100 \\
\hline
\end{tabular}


different type of araucaria. The varieties identified in this study, Do cedo, Do tarde, Cajuvá and Macaco, were also described in different regions of the Urubici and Painel municipalities, both in Santa Catarina State, by Adan et al. (2016). The Do cedo variety ripens between March and April according to the respondents in the present study. Another variety, São José, identified by local people in the Northern Plateau of Santa Catarina State, can ripen in February and March (ZECHINI et al., 2012). Mattos (1994) described four types/varieties of the species and one form, Araucaria angustifolia variety catharinensis, A. angustifolia var. caiova, A. angustifolia var. dependens, $A$. angustifolia var. indehiscensis, and the form $A$. angustifolia var. vinacea, based on several empirical studies in southern Brazil. Reitz and Klein (1966) also identified nine different araucaria types and one form in southern Brazil, such as elegans, sancti josephi, caiova, indehiscensis, semi-alba, alba. We identified local varieties in one specific locality in the MOF landscape, which could fall within the descriptions of varieties in other studies based on morphology or ripening periods. However, different local varieties reflect the use and management of a specific local human population within the entire MOF landscape. Thus, it is important to consider that different botanical varieties are possibly called the same name. On the other hand, it is expected that similar varieties have different local names based on idiosyncratic aspects of use, historical influences, and management.

The present commercialization of different types of pinhões throughout the year, their morphological description, the different types of araucaria identified by interviewees, and the ecological and hypothetical explanations by the local population about pinhão production are some examples of the interaction between araucaria, the landscape, and local communities. The aforementioned recognized practice of seedling suppression, which consists of removing the herbaceous layer for cattle grazing, is another example of landscape transformation. Although the negative perspective, since this can initially damage regeneration (VIBRANS et al., 2011), araucaria responds well to disturbances, regenerates in open landscapes, and its recruitment is dependent on large clearings (PUCHALSKI et al., 2006; RIBEIRO et al., 2012). In addition, during initial development stages, seedlings can be shade tolerant (DILLENBURG et al., 2009). Nevertheless, what has caused the main reduction of araucaria species in the landscape is attributed to historical forest degradation, overexploitation of wood, agricultural expansion and forest fragmentation, rather than the historical use and management of the species' resources by the local communities in a domesticated landscape.

The ethnobotanical semi-structured survey explained the knowledge, use, and local management of araucaria resources. Furthermore, ecological points about seed production, ripening period, commercialization time, variety identification, and insights about pinhão production in open landscapes rather than in dense forests (typically in CU), made by the interviewees, ought to be pointed out as interaction mechanisms that interfere with araucaria conservation. This ecological comprehension of a species by local communities reinforces that it is very likely that over several generations the distribution of araucaria must have been influenced by human populations and was domesticated locally as a biocultural system in a cultural landscape (BERKES; DAVIDSON-HUNT, 2006; LADIO, 2011; REIS et al., 2014).

The cultural landscape theory emphasizes the importance of enhancing conservation mechanisms by recognizing the relevance of traditional populations to the ecological functions of the species, mainly due to local use and management. It could be possible that the CU and cultural landscape approach worked together towards Araucaria angustifolia conservation to maintain ecological functions, seed production, species dispersion, genetic exchange, and the use and preservation of resources by local communities.

\section{Acknowledgments}

The authors thank CNPq for the productivity fellowship awarded to NP, the Santa Catarina Foundation for Science and Research Support - FAPESC, the Brazilian Coordination for the Improvement of Higher Education Personnel (CAPES) for the scholarship awarded to MMT, Mapa's Fund and all the local people from Urubici who contributed information in this study. 


\section{References}

ADAN, N.; ATCHINSON, J.; REIS, M. S.; PERONI, N. Local knowledge, use and management of ethnovarieties of Araucaria angustifolia (Bertol.) Ktze. in the Plateau of Santa Catarina, Brazil. Economic Botany, New York City, v. 70, n. 4, p. 353-364, 2016.

ALBUQUERQUE, U. P.; LUCENA, R. F. P.; ALENCAR, N. L. Métodos e técnicas para coleta de dados etnobiológicos. In: ALBUQUERQUE, U. P.; LUCENA, R. F. P.; CUNHA, L. V. F. C. (Ed.). Métodos e Técnicas na Pesquisa Etnobotânica. 2. ed. Recife: Comunigraf, Brazil, 2008. p. 39-64.

ATKINSON, R.; FLINT, J. Accessing hidden and hard-to-reach populations: snowball research strategies. Social Research Update, Glasgow, v. 49, n. 1, p. 116-142, 2001.

BALÉE, W. Contingent diversity on anthropic landscapes. Diversity, Basel, v. 2, n. 2, p. 163-181, 2010.

BAYLEY, K. D. Methods of social research. New York: Free Press, 1994. 592 p.

BERKES, F.; DAVIDSON-HUNT, I. J. Biodiversity, traditional management systems, and cultural landscapes: examples from the boreal forest of Canada. International Social Science Journal, Malden, v. 58, n. 187, p. 35-47, 2006.

BERNARD, H. R. Research methods in Anthropology: qualitative and quantitative approaches. 4. ed. Oxford: Altamira Press, 2006. $824 \mathrm{p}$

BROOKS, T. M.; MITTERMEIER, R. A.; DA FONSECA, G. A. B.; GERLACH, J.; HOFFMANN, M.; LAMOREUX, J. F.; MITTERMEIER, C. G.; PILGRIM, J. D.; RODRIGUES, A. S. L. Global biodiversity conservation priorities. Science, New York, v. 313, n. 2006, p. 58-61, 2006.

BYG, A.; BALSEV, H. Diversity and use of palms in Zahanema, eastern Madagascar. Biodiversity and Conservation, New York, v. 10, n. 6, p. 951-970, 2001.

CAPPARELLI, A.; HILGERT, N.; LADIO, A. Paisajes culturales de Argentina: pasado y presente desde las perspectivas etnobotánica y paleoetnobotánica. Revista de la Asociación Argentina de Ecología de Paisajes, Buenos Aires, v. 2, n. 2, p. 67-79, 2011.

CARVALHO, P. E. R. Espécies florestais brasileiras: recomendações silviculturais, potencialidades e uso da madeira. Brasília: EMBRAPA/CNPF, 1994. P. 639.

CLEMENT, C. Domesticação de paisagens e plantas amazônicas: a interação de etnobotânica, genética molecular e arqueologia. In: MORCOTE-RIOS, G.; MORA, S. C.; FRANKY, C. C. (Ed.). Pueblos y paisajes antiguos de la selva amazónica. Bogotá: Universidade Nacional de Colombia, Facultad de Ciencias, Taraxacum, 2006. p. 97-112.

CLEMENT, C. R.; JUNQUEIRA, A. B. Between a pristine myth and an impoverished future. Biotropica, New York, v. 42, n. 5, p. $534-536,2010$.

DILLENBURG, L. R.; FRANCO, A. M. S.; COUTINHO, A. L.; KORNDORFER, C. L.; CLEBSHC, C. C.; DUARTE, L. S. Aspectos ecofisiológicos da regeneração de Araucaria angustifolia. In: FONSECA, C. R.; SOUZA, A. F.; LEAL-ZANCHET, N. A.; DUTRA, T., BACKES, A.; GANADO, G. (Ed.). Floresta com Araucária: ecologia, conservação e desenvolvimento sustentável. Ribeirão Preto: Editora Holos, 2009. p. 57-66.
DUARTE, R. I.; DA SILVA, F. A. L. S; SCHULTZ, J.; DA SILVA, J. Z.; REIS, M. S. Características de desenvolvimento inicial em teste de progênie de uma população de araucária na Flona de Três Barras-SC. Biodiversidade Brasileira, Brasília, v. 2, p. 114-123, 2012.

GUERRA, M. P.; SILVEIRA, V.; REIS, M. S.; SCHNEIDER, L. Exploração, manejo e conservação da araucária (Araucaria angustifolia). In: SIMÕES, L. L.; LINO, C. F. (Ed.). Sustentável Mata Atlântica: a exploração de seus recursos florestais. São Paulo: SENAC, 2002. p. 85-102.

IBGE. Manual técnico da vegetação brasileira. Vol. 2. Rio de Janeiro: Instituto Brasileiro de Geografia e Estatística: Diretoria de Geociências, Coordenação de Recursos Naturais e Estudos Ambientais, 2012. $271 \mathrm{p}$.

INCRA. Sistema Nacional de Cadastro Rural. Instituto Nacional de Colonização e Reforma Agrária. 2013. Disponível em: <http:// www.incra.gov.br/sites/default/files/uploads/estrutura-fundiaria/ regularizacao-fundiaria/indices-cadastrais/indices_basicos_2013_ por_municipio.pdf $>$. Acesso em: 6 mar. 2018.

KANIESKI, M. R.; ARAUJO, A C. B.; LONGHI, S. J. Diversity quantification in Mixed Ombrophilous Forest by different alpha indexes. Scientia Forestalis, Piracicaba, n. 88, p. 567-577, 2010.

LADIO, A. Traditional knowledge of edible wild native and exotic plants in the context of cultural change in human populations of arid Patagonia. Bioremediation, Biodiversity and Bioavailability, Middlesex, v. 5, Special Issue 1, p. 60-64, 2011.

LEVIS, C.; COSTA, F. R. C.; BONGERS, F., PEÑA-CLAROS, M.; ClEMENT, C. R.; JUNQUEIRA, A. B.; NEVES, E. G.; TAMANAHA E. K.; et al. Persistent effects of pre-Columbian plant domestication on Amazonian forest composition. Science, New York, v. 355, p. 925-931, 2017.

MACHADO MELLO, A. J.; PERONI, N. Cultural landscapes of the Araucaria Forests in the Northern Plateau of Santa Catarina, Brazil. Journal of Ethnobiology and Ethnomedicine, London, v. 11, n. 1, p. 1-14, 2015

MATTOS, J. R. O Pinheiro brasileiro. Lages: Artes Gráficas, 1994. $225 \mathrm{p}$

MONTEIRO, J. M.; ALBUQUERQUE, A. P.; LINS-NETO, E. M. F.; ARAÚJO, E. L.; AMORIM, E. L. C. Use patterns and knowledge of medicinal species among two rural communities in Brazil's semi-arid northeastern region. Journal of Ethnopharmacology, Shannon, v. 105, n. 1-2, p. 173-186, 2006.

MYERS, N.; MITTERMEIER, R. A.; MITTERMEIER, C. G.; FONSECA, G. A. B.; KENT, J. Biodiversity hotspots for conservation priorities. Nature, London, v. 403, p. 853-858, 2000.

PROBER, S. M.; WALSH, F. J.; O'CONNOR, M. H. Australian aboriginal peoples' seasonal knowledge: A potential basis for shared understanding in environmental management. Ecology and Society, Wolfville, v. 16, n. 2, p. 1-16, 2011.

PUCHALSKI, Â.; MANTOVANI, M.; REIS, M. S. Variação em populações naturais de Araucaria angustifolia (Bertol.) O.Kuntze associada a condições edafo-climáticas. Scientia Forestalis, Piracicaba, n. 70, p. 137-148, 2006.

REIS, M. S.; LADIO, A.; PERONI, N. Landscapes with Araucaria in South America: evidence for a cultural dimension. Ecology and Society, Wolfville, v. 19, n. 2, p. 1-14, 2014. 
REITZ, P. R.; KLEIN, R. M. Araucariáceas. In: REITZ, P. R. (Ed.). Flora ilustrada catarinense. Itajaí: Herbário Barbosa Rodrigues, 1966. p. 3-55.

RIBEIRO, M. C.; METZGER, J. P.; MARTENSEN, A. C.; PONZONI, F. J.; HIROTA, M. M. The Brazilian Atlantic Forest: how much is left, and how is the remaining forest distributed? Implications for conservation. Biological Conservation, Boston, v. 142, n. 6, p. 1141-1153, 2009.

RIBEIRO, T. M.; MARTINS, S. V.; IVANAUSKAS, N. M.; POLISEL, R. T.; SANTOS, R. L. R. Restauração florestal com Araucaria angustifolia (Bertol.) Kuntze no Parque Estadual de Campos do Jordão, SP: Efeito do fogo na estrutura do componente arbustivo-arbóreo. Scientia Forestalis, Piracicaba, v. 40, n. 94, p. 279-290, 2012

RODERJAN, C. V.; GALVÃO, F.; KUNIYOSHI, Y. S.; HATSCHBACH, G. G. As unidades fitogeográficas do estado do Paraná. Ciência \& Ambiente, Santa Maria, v. 24, p. 76-92, 2002.

SHIBATA, M.; COELHO, C. M. M.; ARALDI, C. G.; ADAN, N.; PERONI, N. Qualidade fisiológica e física de sementes de variedades locais de Araucaria angustifolia. Acta Scientiarum, Maringá, v. 38, n. 2, p. 249-256, 2016.
THOMAS, L. F. Climate change and conservation. Acta Silvatica et Lignaria Hungarica, Sopron, v. 8, n. 1, p. 57-74, 2012.

VIBRANS, A. C.; SEVEGNANI, L.; UHLMANN, A.; SCHORN, L. A.; SOBRAL, M. G. GASPER, A. L. de; LINGNER, D. V.; BROGNI, E.; KLEMZ, G.; GODOY, M. B.; VERDI, M. Structure of Mixed Ombrophyllous Forests with Araucaria angustifolia (Araucariaceae) under external stress in Southern Brazil. Revista de Biología Tropical, São José, v. 59, n. 3, p. 1371-1387, 2011.

WREGE, M. S.; SOUZA, V. A.; FRITZSONS, E.; SOARES, M. T. S.; AGUIAR, A. V. Predicting current and future geographical distribution of Araucaria in Brazil for Fundamental Niche Modeling. Environment and Ecology Research, San Jose, v. 4, n. 5, p. 269-279, 2016.

ZECHINI, A. A.; SCHUSSLER, G.; SILVA, J. Z.; MATTOS, A. G.; PERONI, N.; MONTOVANI, A.; REIS, M. S. Produção, Comercialização e identificação de variedades de pinhão no entorno da Floresta Nacional de Três Barras - SC. Biodiversidade Brasileira, Brasília, v. 2, n. 2, p. 74-82, 2012. 


\section{Appendix}

APPENDIX 1: Semi-structured questionnaire applied in the study area. People interviewed were local farmers and seed extractors who directly or indirectly managed (i.e., selling, extracting, self-consumption) araucaria species in the landscape. Questions applied were structured and/or open-ended. The questionnaire involved three main subjects: pinhão commerce, variety identification, and conservation/environmental problems related to the target species.

\begin{tabular}{|c|c|}
\hline \multicolumn{2}{|r|}{ Questionnaire applied in the semi-structured interviews } \\
\hline 1 & How much does the pinhão commerce influence your income? \\
\hline 2 & What is the best period of the year for pinhão commerce? \\
\hline 3 & Which araucaria/pinhão varieties are found on your property? How do you describe them? \\
\hline 4 & Which araucaria varieties do you know? Which months do these varieties have pinhões? \\
\hline 5 & Which variety is more commercialized? Are the consumers aware of the pinhão varieties? \\
\hline 6 & Is there any preference among the consumers for any variety? \\
\hline 7 & $\begin{array}{l}\text { Is there a difference in the quantity of pinhões collected over the years? Did this increase or decrease? What is the } \\
\text { reason for this production change? }\end{array}$ \\
\hline 8 & Could you describe the pinhão production cycle? \\
\hline 9 & What situation could affect pinhão production? \\
\hline 10 & Did the araucaria population increase in recent years? \\
\hline 11 & Do the non-productive araucarias affect productive araucarias? \\
\hline 12 & Are you aware of the legislation concerning São Joaquim National Park? \\
\hline 13 & $\begin{array}{l}\text { Do you respect the environmental legislation? Why? Describe positive and negatives aspects about the influence of } \\
\text { the legal protection of the araucaria population. }\end{array}$ \\
\hline 14 & How do you define the environment? \\
\hline 15 & Do you believe that sustainable management is possible for araucaria species? How would you do this? \\
\hline 16 & $\begin{array}{l}\text { If sustainable araucaria exploitation was allowed, do you think that this situation could createa new precedent to } \\
\text { over-exploitation? }\end{array}$ \\
\hline
\end{tabular}

